\title{
ESPAÇOS, PAÇOS, TEMPLOS E MOSTEIROS: A AMBIENTAÇÃO EM ALEXANDRE HERCULANO
}

\section{SPACES, PALACES, TEMPLES AND MONASTERIES: THE AMBIANCE IN ALEXANDRE HERCULANO}

\author{
Eduardo Soczek Mendes* \\ UFPR - Unioeste
}

\begin{abstract}
Resumo: As pormenorizações de ambientes ou descrições de patrimônios histórico-arquitetônicos são recorrentes na produção narrativa de Alexandre Herculano (1810-1877). Quando não pela voz narrativa, o próprio autor, em textos paraliterários - prefácios e notas -, discorre acerca de mosteiros, templos, paços e outros ambientes muito significativos para o território, a História e a cultura de Portugal. O presente trabalho averigua como são realizadas as ambientações nos romances históricos O Bobo (1128), Eurico, o presbítero e $O$ Monge de Cistér ou a época de D. João I, além de também analisar, sob a mesma proposta, alguns textos literários coligidos em Lendas e Narrativas. Embasados nas propostas de Eduardo Lourenço (1992), György Lukács (2011), Maria de Fátima Marinho (1999) e Mikhail Bakhtin (1997), constatamos que as exaustivas pormenorizações de ambientes, em Herculano, além de compor harmonicamente a economia das narrativas, dialogam, em suas particularidades, com o contexto de publicação das obras no Portugal oitocentista.
\end{abstract}

Palavras-chave: Alexandre Herculano. Ambientação. Descrições.

\begin{abstract}
The details of environments or descriptions of historical-architectural heritage recur in Alexandre Herculano's (1810-1877) narrative production. When not through the narrative voice, the author himself, in paraliterary texts - prefaces and notes - discusses monasteries, temples, palace and other environments that are very significant for Portugal's territory, history and culture. The present work investigates how the settings are made in the historical novels O Bobo (1128), Eurico, o presbítero and O Monge de Cistér ou a época $D$. João $I$, and also analyze, under the same proposal, some collected literary texts in Lendas e Narrativas. Based on the proposals of Eduardo Lourenço (1992), György Lukács (2011), Maria de Fátima Marinho (1999) and Mikhail Bakhtin (1997), we find that the exhaustive details of environments in Herculano, besides harmonically composing the economics of narratives, dialogue, in their particularities, with the context of publication of works in nineteenth-century Portugal.
\end{abstract}

Keywords: Alexandre Herculano. Ambiance. Descriptions.

\footnotetext{
* Doutorando na Universidade Federal do Paraná, pesquisador vinculado ao CEP (Centro de Estudos Portugueses) da mesma Universidade e Professor de Literatura Portuguesa e Teoria da Literatura, com vínculo de colaborador, do Departamento de Letras da Universidade Estadual do Centro-Oeste (Santa Cruz, Guarapuava, Paraná).
} 


\section{Introdução}

Chegam até nós, quotidianamente, inúmeras imagens: utilizando aparelhos eletrônicos é possível fotografar ou filmar inúmeras situações ordinárias e, igualmente, se desfazer desses materiais com muita rapidez. Pelas redes sociais também nos chegam grande quantidade de imagens a todo o momento e há, inclusive, as redes exclusivas para o compartilhamento de imagens. Mesmo a produção literária contemporânea, de um modo geral, parece pormenorizar menos os ambientes de circunscrição de suas narrativas: há algumas em que as descrições se assemelham ao foco de uma câmera dando notícias pontuais do que se está descrevendo, sem haver as longas considerações da voz narrativa. Entretanto, quando nos deparamos com textos literários mais antigos com as suas costumeiras pormenorizações exaustivas, podemos, inclusive, achá-las enfadonhas ou mesmo desnecessárias, mas também devemos recordar que as imagens circulavam muito menos. A nossa proposta é, portanto, averiguar, sob a pena de Alexandre Herculano (1810-1877), as funções das longas ambientações na economia das narrativas.

Nas diversas produções literárias desse autor do Romantismo Português são frequentes as longas pormenorizações de ambientes e, se pensarmos que Herculano se dedicou bastante à composição do romance histórico ${ }^{1}$ ou de narrativas mais breves com as características de romance histórico, é possível compreender as motivações para o uso de extensas descrições dos ambientes. Ian Watt (2010, p. 27), ao caracterizar o surgimento do gênero "romance” e algumas de suas particularidades, afirma que "[...] o espaço é necessariamente o correlativo do tempo. [...] não conseguimos facilmente visualizar um momento particular da existência sem situá-lo também em seu contexto espacial”. Isso porque o romance, na concepção de Watt, é um relato bastante particularizado da experiência humana e exige informações precisas e não-genéricas:

[...] o romance constitui um relato completo e autêntico da experiência humana e, portanto, tem a obrigação de fornecer ao leitor detalhes da história como a individualidade dos agentes envolvidos, os particulares das épocas e locais de suas ações - detalhes que são apresentados através de um emprego da linguagem muito mais referencial do que é comum em outras formas literárias. (WATT, 2010, p. 34)

Ora, se em textos clássicos e anteriores ao século XVIII, como "Na tragédia, na comédia e na narrativa o lugar era tradicionalmente quase tão vago quanto o tempo.” (WATT, 2010, p. 27), no romance, o detalhamento do espaço e tempo se faz indispensável, pois circunscreve onde se passou aquela experiência humana que se pretende relatar. E, quanto mais, se tratarmos do romance histórico, em que a sua trama está necessariamente relacionada com a ambiência em um determinado espaço e tempo.

Vale recordar que, por diversas vezes, o romance histórico tradicional foi relacionado com o ensino didático da História, pois, “[...] o grande público lê com mais facilidade um romance do

\footnotetext{
${ }^{1}$ Alexandre Herculano (19--b, p. VI-VII), na “Advertência da Primeira Edição” de Lendas e Narrativas, afirma que esses textos foram "[...] as primeiras tentativas do romance historico que se fizeram na lingua portuguesa. Monumentos dos esforços do autor para introduzir na litteratura nacional um genero amplamente cultivado nestes nossos tempos em todos os paizes da Europa [...], ao escrevê-las, o auctor se via de crear a substancia e a fórma; porque para o seu trabalho faltavam absolutamente os modelos domesticos.”. De fato, Almeida Garrett (1799-1854) só publicaria o primeiro volume do romance O Arco de Sant'Ana: Crónica portuense em 1845, enquanto que os textos que comporiam os tomos de Lendas e Narrativas, publicados em 1851, já haviam sido divulgados no semanal O Panorama entre 1839 e 1844. Daí vem o pioneirismo de Herculano, ao que se sabe, em relação à produção de narrativas históricas em Língua Portuguesa.
} 
que uma obra científica” (MARINHO, 1999, p. 16) e mesmo Alexandre Herculano, em Scenas de um anno da minha vida ${ }^{2}$, discutiu, após relatar a sua experiência frente ao um velho cego e pedinte, sobre a elaboração literária e também sobre a escrita científica da História:

Foi então que povoei de successos a sua vida passada [do velho pedinte]. Quem sabe se a imaginação me disse mais verdade do que me diria a narração do mendigo! Novella, historia, qual destas duas cousas é mais verdadeira? Nenhuma, se o affirmarmos absolutamente de qualquer dellas. Quando o caracter dos individuos ou das nações é sufficientemente conhecido, quando os monumentos e as tradições, e as chronicas desenharam esse caracter com pincel firme, o novelleiro póde ser mais veridico do que o historiador; porque está mais habituado a recompor o coração do que é morto pelo coração do que vive, o genio do povo que passou pelo do povo que passa. Então de um dicto, ou de muitos pensamentos, não reduzidos á lembrança positiva, não traduzidos, até, materialmente; de um facto ou de muitos factos deduz um affecto ou muitos affectos, que se não revelaram. Esta é a historia intima dos homens que já não são: esta é a novella do passado. Quem sabe fazer isto chama-se Scott, Hugo, ou de Vigny, e vale mais e conta mais verdades que boa meia-duzia de bons historiadores. / Porque estes recolhem e apuram monumentos e documentos, que muitas vezes foram levantados ou exarados com o intuito de mentir á posteridade, em quanto a historia da alma do homem deduzida logicamente da somma das suas acções incontestaveis, não póde falhar, salvo se a natureza podesse mentir e contradizer-se, como mentem e se contradizem os monumentos. (HERCULANO, 19--e, p. 103-104)

O escritor, numa concepção muito própria da época, reflete sobre como a efabulação ficcional pode também trazer à luz a “verdade” e propor a ponderação crítica, pois reflete não apenas sobre as documentações oficiais - que podem ser lavradas e talhadas para a construção de uma memória desejada: talvez a memória perpetuada pelos nomes dominantes da História - enquanto que a efabulação pode dar voz aos anônimos, pode particularizar as suas histórias, anseios e sofrimentos, já que a inscrição da memória dos documentos é bastante manipulável, a ficção pode também manipular a História, com maior liberdade, dando voz aos que não tem voz dentro dos monumentos e registros documentais. Essa era a tarefa, para Herculano, de escritores que cultivaram o romance histórico, como Walter Scott (1771-1832), Victor Hugo (1802-1885) e de Alfred de Vigny (1797-1863). De maneira semelhante, reflete Watt (2010, p. 13; 16):

O romance é a forma literária que reflete mais plenamente essa reorientação individualista e inovadora. / [...] o enredo envolveria pessoas específicas em circunstâncias específicas, e não, como fora usual no passado, tipos humanos genéricos atuando num cenário basicamente determinado pela convenção literária adequada. (WATT, 2010, p. 13; 16)

Tal especificidade proposta por Watt pode ser verificada, a título de curiosidade, no romance histórico $O$ Bobo (1128) ${ }^{3}$, de Herculano: o espaço e a temporalidade da obra estão muito

\footnotetext{
${ }^{2}$ Optamos em manter a ortografia conforme as edições que consultamos. A obra Scenas de um anno da minha vida é o resultado da transcrição de manuscritos de Herculano e que vieram a público postumamente.

${ }^{3}$ O Bobo (1128) foi publicado em 1843 no semanário O Panorama. Em 1846, uma versão sem a autorização de Herculano circulou no Brasil e, somente em 1878, após a morte do escritor, saiu, em Portugal, em tomo.
} 
bem delimitados - sendo que a data da circunscrição do enredo, por exemplo, acompanha o próprio título da narrativa, conforme irá ocorrer em muitas outras produções de Herculano, sobretudo as que estão coligidas em Lendas e Narrativas (1851) - e a personagem do truão medieval atua, dentro do enredo do romance, como modificador da História, pois a sua vingança pessoal favorece a independência do reino de Portugal. Maria de Fátima Marinho (1999, p. 23) chama a atenção para a ocorrência disso em prosas contemporâneas: "Na ficção das últimas décadas, os marginais assumem um papel diferente, embora não menos importante a focalização é-lhes, por vezes, atribuída, modificando o sentido canónico da História”. Ora, mesmo levando em consideração a importância que o narrador de $O$ Bobo (1128) dá ao truão medieval, explicando-o como uma figura política de suma importância para a Idade Média, porque, "Naquella epocha o cargo de truão correspondia até certo ponto ao dos censores da republica romana” (HERCULANO, 19--c, p. 26), encontramos no romance de Herculano a particularização e a atribuição da relevância de uma personagem que não se destaca historicamente como o primeiro rei de Portugal, D. Afonso Henriques (1109-1185), ou a sua mãe, D. Tareja de Leão (1080-1130). Portanto, já em O Bobo (1128), a personagem à margem ganha muita notoriedade dentro da economia do romance e dentro da História: é a didática de expor como os que não eram apenas os membros da aristocracia - classe em crise pelas profundas mudanças que obtiveram o estopim nas Revoluções Industrial e Francesa do século XVIII e no contexto oitocentista português - os agentes da História. Corrobora a essas afirmações o fato de que a burguesia passou a ser uma classe consumidora de Literatura, sobretudo porque os periódicos, num modelo de popularização da ilustração, facilitavam o acesso aos textos romanescos e os livreiros acabaram “[...] transformando a literatura num produto como qualquer outro” (WATT, 2010, p. 56).

Ainda no campo das transformações sociais, György Lukács aponta como o surgimento do romance histórico estava intimamente relacionado com os acontecimentos do período:

Primeiro foi a Revolução Francesa, as guerras revolucionárias, a ascensão e a queda de Napoleão que fizeram da história uma experiências das massas, e em escala europeia. Entre 1789 e 1814, as nações europeias viveram mais revoluções que em séculos inteiros. E a celeridade das mudanças confere a essas revoluções um caráter qualitativamente especial, apaga nas massas a impressão de "acontecimento natural”, torna o caráter histórico das revoluções muito mais visível do que costuma ocorrer em casos isolados. [...] fortalece-se extraordinariamente o sentimento de que existe uma história, de que essa história é um processo ininterrupto de mudanças e, por fim, de que ela interfere diretamente na vida de cada indivíduo. (LUKÁCS, 2011, p. 38, grifo do autor)

E, particularmente no contexto português do século XIX, não podemos nos olvidar de que, conforme refere Eduardo Lourenço (1992, p. 85), “Portugal é, de 1808 a 1820, um País invadido, emigrado ou subalternizado pela presença militar ostensiva do Estrangeiro”, pois desde as invasões napoleônicas, a fuga da corte para o Brasil, as Revoltas Vintistas, que exigiam o imediato retorno de D. João VI (1767-1826) e a instauração de um governo Liberal, as tentativas de golpe com a participação de D. Carlota Joaquina (1775-1830) e do infante D. Miguel (1802-1866), a instabilidade política e econômica imperou em Portugal. E, para além desses acontecimentos, entre os anos de 1828 e 1834, aconteceram as Guerras Liberais ou Guerra Civil 
Portuguesa: um confronto entre os irmãos D. Miguel e D. Pedro (1798-1834) pela sucessão do trono e, igualmente, entre Absolutistas, partidários de D. Miguel, e Liberais, seguidores de D. Pedro. Isto é, o confronto era também no campo dos modelos de governo para o país e os Liberais acabaram por vencer.

Este preâmbulo se faz necessário para que compreendamos o "[...] sentimento de fragilidade ôntica relativo à existência pátria durante todo o século XIX” (LOURENÇO, 1992, p. 86 , grifo do autor) e que

Se Herculano se descobre e inventa romancista pseudo-medievalizante e historiador, não é por amor do passado enquanto tal, por mais glorioso, mas como prospector do tempo perdido de Portugal, cuja decifração lhe é vital para se situar como homem, cidadão e militante num presente enevoado e oscilante. Só assim julga possível modelar o perfil futuro da incerta forma histórica em que se converteu a sua Pátria. (LOURENÇO, 1992, p. 82-83, grifo do autor)

O termo "pseudo-medievalizante”, utilizado por Lourenço, remonta à ideia de que Herculano, de fato, não conseguiria, como também qualquer outro escritor de romance histórico, representar perfeitamente o que foi a Idade Média: a sua escrita era uma reelaboração de um outro período histórico e sob o prisma de seu conhecimento como homem oitocentista. Todavia, o que é mais interessante na afirmação de Lourenço é que as remissões de Herculano ao passado não são por simples gosto ou ingenuidade: elas revelam a busca pela identidade nacional num momento de profunda névoa e de forte influência estrangeira, desde a penetração ideológica do Iluminismo em Portugal até a presença física do exército napoleônico e de oficiais ingleses no território português. Obviamente, Herculano viveu a maior parte de sua vida já sob a batuta dos Liberais, porém havia muito o que reconstruir em Portugal e também pensar quais os rumos o país tomaria. Voltar o olhar ao passado não era, portanto, simplesmente uma fuga do presente caótico, mas sim uma maneira de refletir sobre o presente e o futuro - "É ao passado e no passado - mas por causa do presente” (LOURENÇO, 1992, p. 86). E uma das maneiras de remontar o passado foi a circunscrição espaciotemporal nas narrativas históricas.

\section{A construção da ambientação em Alexandre Herculano}

De acordo com Marinho (1999, p. 57),

Basta abrirmos a obra de romancista de Herculano que logo encontraremos esses topoi que imediatamente nos situam no tempo e no lugar pretendidos. A indistinção espácio-temporal presente, por vezes, noutro tipo de textos está, por definição, portanto, excluída do romance histórico, de tal forma é aí importante [...]. (MARINHO, 1999, p. 57)

Obviamente, como bem propõe a autora, para o romance histórico, o espaço e o tempo devem estar claramente referenciados, já que deles dependem muito a elaboração do enredo: se a narrativa se propõe como didática e se nela podem estar inseridas formas de se fazer pensar as crises pretéritas e presentes, é fundamental que se esteja claro em que momento a história se desenrola e em que lugar. Contudo, de que forma e com qual intuito podem ser realizadas 
essas reconstruções de ambientes? Mikhail Bakhtin (1997, p. 109, grifos do autor) chama a nossa atenção para o fato de que

A criação verbal não cria uma forma espacial externa pois não lida com um material espacial como sucede com as artes picturais, plásticas, gráficas; seu material - a palavra [...] - não é um material espacial em sua substância [...]; mas o objeto estético não é, naturalmente, constituído somente de palavras, ainda que a parte verbal seja importante nele, e esse objeto da visão estética possui uma forma espacial interna artisticamente significante que é representada pelas palavras da obra [...]. (BAKHTIN, 1997, p. 109, grifo do autor)

Isto é, quando os narradores pormenorizam os ambientes, como se valem de palavras para realizarem a descrição, não criam uma forma espacial palpável, mas o recriam pelas descrições e, podem, dessa maneira, privilegiar alguns pontos ou outros dentro da obra escrita, já que há “[...] a passividade espacial e visual que acompanham nossa percepção: a palavra serve para representar uma espécie de dado espacial já pronto” (BAKHTIN, 1997, p. 111). Por isso, ao averiguarmos como acontecem as construções dos ambientes arquitetônicos nas diversas obras de Herculano - e também a relação dessas elaborações com a economia interna de seus enredos - é necessário termos em mente que, conforme propõe Bakhtin (1997, p. 114, grifo do autor),

O que caracteriza o ambiente é, acima de tudo, a disposição formal, externa, plástico-pictural [...]. Na criação verbal, esse aspecto não alcança uma perfeição externa visual (na representação), mas equivalentes emotivo-volutivos de uma representação visual correspondem a esse todo plástico-pictural extra-significante. (BAKHTIN, 1997, p. 114, grifo do autor)

Portanto, não há uma perfeição externa e visual das representações dos ambientes realizadas por palavras, mas as representações estão bastante ligadas à interpretação de quem as descreveu e também de quem as recebe. Averiguaremos, todavia, em Herculano, como essas elaborações figuram em suas produções ficcionais: quais são as interpretações descritivas dos narradores e como se sustentam perante o contexto da narrativa.

Vale ressaltar que, quando nos referimos à construção da ambientação em Herculano, não estamos nos referindo apenas às descrições arquitetônicas dos prédios e patrimônios, mas pretendemos analisar os espaços descritos que envolvem muito além das estruturas construídas, conforme aponta Joana Balsa de Pinho, numa perspectiva da herança religioso-arquitetônica em Portugal:

O património edificado vai muito além da estrutura construída; pela sua natureza, é o suporte e o contexto de muitas outras artes, móveis e integradas, de escultura à pintura de cavalete, passando pela azulejaria, a pintura mural, os embrechados, a talha, o mobiliário, os vitrais, os estuques, mas também, num domínio mais imaterial, a música, as procissões e as próprias celebrações litúrgicas. Esta característica ímpar da arquitetura conjuga-se com a quadrimensionalidade (espaço-tempo) que lhe é inerente. (PINHO, 2017, p. 484) 
Obviamente, a autora se atém muito mais aos ambientes religiosos (e não são somente eles que figuram na produção de Herculano). Porém, podemos ter a ideia, pelas propostas de Pinho, de que as ambientações envolvem significados para além das composições de construção: há a arte que pode adorná-los, mas há também o significado do espaço: para o que é utilizado, por exemplo, e o que isso significa dentro da cultura local. Não pretendemos, até mesmo pelo caráter deste estudo, esgotar ou traçar um trabalho definitivo sobre as representações espaciais em Alexandre Herculano, até porque a temática é muito abundante na escrita literária do autor, além de poder figurar com causas bastante específicas de acordo com o momento da obra e de acordo com a obra em que aparecem. A nossa intenção primeira é a de chamar a atenção para esse topoi e, selecionados alguns trechos das mais distintas narrativas, analisá-las sem perder de vista o contexto de publicação e a economia interna em que as pormenorizações estão inseridas.

\section{Espaços que revisitam a cultura pátria}

Segundo Marinho (1999, p. 58, grifo da autora), as "Exaustivas descrições de cidades, castelos e monumentos [...] contribuem também para acentuar a cor local”, ou seja: é possível afirmar que, normalmente, as pormenorizações de ambientes, realizadas sob a pena de Herculano, são formas de recompor os espaços que nos fazem visualizar melhor a cultura de Portugal.

Iniciaremos, portanto, a nossa análise de excertos descritivos com “O Alcaide de Santarém (950-961)”, coligida em Lendas e Narrativas. Ora, já pelas datas que acompanham o título, percebemos que a narrativa está ambientada antes mesmo da formação de Portugal como Estado independente ${ }^{4}$ e que se trata do período de dominação islâmica na Península Ibérica ${ }^{5}$. Na segunda parte de “O Alcaide de Santarém (950-961)” segue a seguinte descrição:

O luar de noite serena d'abril bate pelos jardins, que se dilatam desde o alcassar até Guad-al-kebir, e alveja trémulo pelas fitas cinzentas dos caminhos tortuosos, em que parecem enredados os bosquesinhos de arbustos, [...] onde a larangeira, o limoeiro e as demais arvores fructiferas, trazidas da Persia, da Syria e do Catay, espalham os aromas variados das suas flores. Lá ao longe, Cordova, a capital da Hespanha mussulmana, repousa da lida diurna, porque sabe que Abdu-r-rahman III, o illutre khalifa, véla pela segurança do imperio. A vasta cidade repousa profundamente, [...]. Das almadenas de seiscentas mesquitas não soa uma unica voz de almuaden, e os sinos das egrejas mosarabes guardam tambem silencio. As ruas,

\footnotetext{
${ }^{4}$ De acordo com José Mattoso (2001, p. 35), foi “[...] a partir da Batalha de S. Mamede (1128), por meio da qual os barões portucalenses, com o apoio do arcebispo de Braga, depois de terem obtido o apoio ativo de Afonso Henriques, expulsaram do condado Fernão Peres de Trava e a rainha D. Teresa”, que houve uma importante cisão entre o Condado de Portucale e a Galícia. Entretanto, o reconhecimento oficial da independência do Reino de Portugal só veio em 1179, com a Bula Papal Manifestis Probatum, firmada pelo Papa Alexandre III (1100-1181).

${ }^{5}$ Os muçulmanos passaram a dominar a Península Ibérica a partir do século VIII. De acordo com Fortunato de Almeida (1967, p. 69), "A monarquia visigótica veio a acabar pela invasão árabe no tempo do rei Rodrigo, que se apoderara do trono com o favor dos nobres, por não quererem estes reconhecer o filho de Vitiza (710).” O romance histórico Eurico, o presbítero, de Herculano, retrata esse declínio visigótico e a penetração árabe na Península. É complexo o período de quase 800 anos de presença islâmica no território, pois os reinos muçulmanos não eram unificados e, muitos deles, possuíam rixas internas. Também as fronteiras desses reinos árabes foram diferentes e oscilaram em determinados momentos. Já no capítulo XIX de Eurico, o presbítero, a "Conclusão” da ficção, se faz menções à histórica Batalha de Cangas de Onis (722), demonstrando que houve, desde o princípio, resistência cristã. Entretanto, posteriormente, também houve convivência harmoniosa entre membros muçulmanos e cristãos nos períodos e territórios dominados pelo Islão. Um dos objetivos, porém, do primeiro rei de Portugal (séc. XII) foi a conquista dos territórios que estavam sob o domínio muçulmano, como as cidades de Lisboa, Santarém e Sintra.
} 
as praças, os azokes ou mercados estão desertos. Sómente o murmurio das novecentas fontes ou banhos publicos, destinados ás abluções dos crentes, ajuda o zumbido nocturno da sumptuosa rival de Bagdad. (HERCULANO, 19--b, p. 15-16)

Ao descrever a cidade de Córdoba, que atualmente pertence à Espanha, o narrador menciona Abderramão III (891-961) ou Abdu-r-rahman, o oitavo Emir de Córdoba, considerado um dos mais bem sucedidos príncipes muçulmanos na Península Ibérica, mas também se vale de uma descrição bastante peculiar se comparada a outras obras de Herculano: abundam vocábulos e termos de origem árabe. O narrador refere, na ambientação, o alcácer - fortaleza ou castelo fortificado, de origem moura, para a residência do governador - e as várias mesquitas, templos do islamismo, com as suas almádenas - as torres ou miranetes com balcões salientes - de onde o almuadem (ou muezim) conclama os fiéis do islão, em alta voz, para as orações diárias. Outro termo de origem árabe, utilizado pela voz narrativa no excerto transcrito, é azoque, que refere o mercado ou a feira: não é, certamente, ingênua a seleção vocabular para a pormenorização da cidade, pois o narrador poderia utilizar outros termos mais correntes de nossa língua, mas houve a adoção dos vocábulos de origem mourisca. Percebamos, contudo, que a descrição das Espanhas muçulmana não é feita de modo depreciativo: um dos componentes culturais dos povos da Península Ibérica é a marca da presença árabe em seu território e isso, por diversas vezes, soou como exótico para o restante dos países europeus ou foi menosprezado pelo restante da Europa. Em Herculano, porém, a herança árabe foi, muitas vezes, exaltada: o narrador refere, por exemplo, a presença das árvores frutíferas trazidas do Médio Oriente e descreve Córdoba como suntuosa, rivalizando com Bagdá. Também as fontes e banhos públicos, conhecidos empreendimentos arquitetônicos dos árabes, são mencionados e a convivência pacífica entre os cristãos e muçulmanos está presente arquitetonicamente na presença das mesquitas e igrejas moçárabes, aos quais o narrador faz alusões.

A escolha em mencionar os sinos das igrejas moçárabes não é ingênua: essas construções não são apenas componentes da paisagem urbana da cidade sob o domínio muçulmano, mais do que isso, os templos moçárabes e as mesquitas islâmicas são exemplos da coexistência harmoniosa entre muçulmanos e cristãos, que é também um dado muito peculiar da Península Ibérica. Fortunato de Almeida (1967, p. 71, grifo do autor) explica que "Com o nome de moçárabes designavam os sarracenos os povos que, sem abandonarem a própria religião, recebiam o jugo muçulmano. Moçárabe deriva de Mocetárabe, que significa feitos ou tornados árabes”, isso porque,

Em geral, a doutrina seguida pelos árabes em suas conquistas, era que os povos vencidos deviam converter-se ao islamismo, ou pagar uma contribuição territorial e outra pessoal. [...] e na península aconteceu, como noutras partes, que os muçulmanos preferiam ver avultar os impostos a que aumentasse o número dos adeptos do Corão. (ALMEIDA, 1967, p. 71)

Ou seja, isso tudo garantiu aos cristãos “a posse tranquila de suas [...] igrejas e o livre exercício do culto” (ALMEIDA, 1967, p. 71) mesmo sob o comando dos muçulmanos. Formouse, dessa maneira, uma sociedade de múltiplos câmbios culturais na religiosidade, na língua, na arquitetura e que ajudaram a talhar as expressões culturais de Portugal. 
Os visigodos, anteriores aos árabes, também deixaram as suas marcas culturais pela Península Ibérica. O romance histórico Eurico, o presbítero ${ }^{6}$, ambientado no século VIII, possui descrições da arquitetura dos prédios visigóticos, na nítida tentativa de uma circunscrição mais apurada de um período tão longínquo temporalmente e do qual os leitores teriam poucas referências:

O presbitério, situado no meio da povoação, era um edifício humilde, como todos os que ainda subsistem alevantados pelos Gôdos sôbre o solo da Espanha. Cantos enormes sem cimento alteiam-lhe os muros; cobre-lhe o âmbito um teto achatado, tecido de grossas traves de carvalho subpostas ao ténue côlmo: o seu portal profundo e estrito pressagia de certo modo a misteriosa portada da catedral da Idade Média: as sua janelas [...] são como um tipo indeciso e rude das frestas que, depois, alumiaram os templos edificados no décimo-quarto século, [...] se o presbitério visigótico, no escasso da claridade, se aproxima do tipo cristão de arquitetura, no resto revela que ainda as idéias grosseira do culto de Odim não se tem apagado de todo nos filhos e netos dos Bárbaros, convertidos há três ou quatro séculos à crença do Crucificado. (HERCULANO, 19--a, p. 7-8)

Ao remontar o passado visigótico, a voz narrativa do romance discorre sobre o presbitério - o templo - visigótico: na pormenorização, alguns aspectos, como os pórticos e a ausência de luz do prédio, são retratados como um prenúncio das catedrais medievais do século XIV, mas o presbitério visigótico também resguarda, segundo o narrador, as feições dos cultos da mitologia nórdica, que também compõem a formação cultural de Portugal.

No mesmo romance, no capítulo XVI, intitulado “O Castro Romano”, o narrador retoma ainda as heranças arquitetônicas do Império Romano, que também dominou a Península Ibérica, e, portanto, também integram as origens pátrias:

Na margem direita do rio, [...] viam-se ainda no princípio do oitavo século as ruínas de antigo castro ou arraial romano. Jaziam estas em uma espécie de promontório de rochas, pendurado sôbre a veia de água [...] e no alto de uma ladeira íngreme que conduzia à entrada daquele circuito achavam-se os vestígios de uma porta de campo, provàvelmente a pretória: a decúmana [...] / Descavalgados, os dois guerreiros tomaram nos braços a irmã de Pelágio e foram recliná-la sôbre um montículo coberto de relva e musgos, que, pela sua situação no lugar onde, provàvelmente, ficava a divisão entre o pretório e a parte inferior do campo, dava indícios de ser o assento das aras dos deuses, que os Romanos usavam colocar no meio dos arraiais. (HERCULANO, 19--a, p. 221; 225)

Assim como o narrador de "O Alcaide de Santarém (950-961)", ao tratar da paisagem árabe, se valeu de vocábulos próprios de tal expressão cultural, a voz narrativa de Eurico, o presbítero, ao tratar das ruínas dos tempos da dominação romana, fará alusões às instituições e costumeiras disposições das construções dos Césares: as ruínas da fortaleza - o castro conservam uma possível porta da decúmana - termo usado para designar, entre os romanos, um caminho ou rua que se orientava dentro dos castros ou povoações romanas. A remissão ao

\footnotetext{
${ }^{6} \mathrm{O}$ romance Eurico, o presbítero “[...] teve fragmentos publicados, na Revista Universal Lisbonense e no periódico O Panorama, em 1843, sendo publicada em volume completo no ano seguinte” (MENDES, 2017, p. 11).
} 
pretório - instituição do Império e das colônias de Roma, que poderia servir de quartel, tribunal e residência do procurador romano nas províncias - também está presente na pormenorização do narrador, além do possível altar - a ara - erigido aos deuses na centralidade da fortificação.

O efeito da pormenorização, além de aproximar o leitor da circunscrição temporal da narrativa, pode ser, com base nas informações contextuais que já apresentamos neste estudo, também o de fazer pensar os destinos pátrios: o que foi o espaço em que habitavam antes da formação do Estado Português e por quais vicissitudes havia passado. Detalhar as ruínas romanas, o presbitério visigótico ou a cidade árabe era uma maneira de recordar os germens da nacionalidade portuguesa, afinal em nota a Eurico, o presbítero, o autor tece a sua justificativa para a elaboração do romance histórico em tal período:

A Espanha romano-germânica transformou-se na Espanha rigorosamente moderna no terrível cadinho da conquista árabe. A obra literária [...] relativa a essa transição deve combinar as duas fórmulas - indicar as duas extremidades a que se prende; fazer sentir que o [...] herói se vai transformar em cavaleiro; que o servo, entidade duvidosa entre homem e coisa, começa a converter-se em altivo e irrequieto burguês. (HERCULANO, 19--a, p. 287)

Isto é, o escritor dá mostras, em nota explicativa, de que, de fato, a sua intenção é pedagógica com a publicação do romance histórico: quer que o público perceba as raízes da cultura pátria ou da sociedade contemporânea nas instituições e estamentos do passado e não elege a circunscrição temporal da narrativa ao acaso, pois o período em que Eurico, o presbítero está ambientada é um momento chave dentro da História das sociedades da Península Ibérica, como muito bem propôs Marinho (1999, p. 53):

Se, por um lado, o estudo da História apaixonou intelectuais românticos, ao ponto de Herculano, por exemplo, ter percorrido o país à procura de documentos que esclarecessem a vida medieval portuguesa, por outro, não é menos verdade que em certa efabulação com base histórica, isto é, a criação de universos, simultaneamente fictícios e referenciais, foi também uma constante de um período específico do Romantismo europeu e português. A voga inglesa, francesa ou italiana de reconstituição histórica do passado, na busca de uma identidade nacional que teria ficado abalada com as convulsões sociopolíticas do fim do século XVIII, início do XIX, estende-se também a Portugal. (MARINHO, 1999, p. 53)

A autora recorda que Herculano está vivendo e produzindo em um contexto maior e que, portanto, não é o único autor do contexto a trabalhar acuradamente as pormenorizações em sua produção literária, já que a recorrência desse tipo de escrita é muito maior e não está apenas circunscrito ao Portugal oitocentista ${ }^{7}$. Entretanto, é possível afirmar que Herculano deu tonalidade portuguesa às suas descrições, pois tocou em particularidades da cultura portuguesa e de suas construções. Outro exemplo disso, pode ser verificado em “O Parocho da Aldeia (1825)”, também inserida em Lendas e Narrativas:

\footnotetext{
${ }^{7} \mathrm{O}$ romancista francês Victor Hugo, por exemplo, elabora, por meio da voz narrativa de Notre-Dame de Paris (1831), uma longa digressão acerca da arquitetura da catedral parisiense, comparando a construção a um livro de pedra. Já o português Almeida Garrett também é conhecido pelas suas longas pormenorizações referidas pelos narradores de O Arco de Sant'Ana (1845) e Viagens na minha terra (1846). Ou seja, a tendência das descrições espaciais não a inaugurou Herculano, mas a utilizou com muito proveito em suas obras.
} 
No alto da povoação ficava o presbyterio. Era a igreja [...] daquelle gosto duvidoso entre a architectura christan, que expirava, e a da restauração romana, que ainda se não comprehendia: era um desses templosinhos construidos no fim do reinado de D. Manuel e durante o de D. João III, de que tão grande numero resta ainda pelas parochias de Portugal [...]. A devoção nesses tempos era objecto de luxo: edificar uma igreja ou uma capella equivalia a ter hoje camarote em S. Carlos ou cocheiro com estrigas de linho na cabeça e chapéu triangular. (HERCULANO, 19--b, p. 121)

O narrador refere, ao descrever a igreja da aldeia, a um estilo duvidoso - não no sentido pejorativo, mas de combinação - entre a arquitetura cristã que já estava em seu crepúsculo, ou seja, o gótico medieval, e o renascimento pelo gosto da arquitetura de Roma. Se levarmos em consideração essas afirmações e, igualmente, os períodos referidos pela voz narrativa, de que a igreja era pertencia a um estilo muito cultivado em Portugal entre o fim do reinado de D. Manuel I (1469-1521) e o início do governo de D. João III (1502-1557), saberemos que a pormenorização é de um templo no estilo Manuelino, ou também chamado de Gótico Português Tardio. Tiago Cruz (2017, p. 79) esclarece que

A arquitetura que habitualmente designamos como "manuelina”, salvaguardando as suas manifestações mais precoces, foi desenvolvida e consolidada durante o reinado de D. Manuel I (1495-1521), acompanhando o período inicial do de D. João III (1521-1557). (CRUZ, 2017, p. 79)

Isto é, a proposta de Cruz corrobora a ideia de que o narrador de "O Parocho da Aldeia (1825)”, ao discorrer sobre o templo local, está se referindo à concepção espacial Manuelina. Mas, o que há de importante neste dado presente na narrativa de Herculano? o estilo Manuelino foi, muitas vezes, considerado como uma forma arquitetônica nacional e que nem sempre seguiu as ortodoxias das formas cultivadas em outros lugares de Europa (CRUZ, 2017, p. 80). Se levarmos em conta a economia interna de “O Parocho da Aldeia (1825)”, que não resguarda as características de um romance histórico, perceberemos, no entanto, que há na narrativa uma discussão acerca da nacionalidade e religiosidade de Portugal perante as particularidades de países como Inglaterra, com a sua Reforma Protestante (séc. XVI), e de França, com os ideais Iluministas. Ora, a evocação, ainda que rápida, de um hipotético estilo arquitetônico nacional não é, mais uma vez, ingênua, pois dialoga com o todo da narrativa de Herculano. É interessante frisar ainda que o narrador faz uma menção às devoções pretéritas, associadas ao prestígio: edificar uma igreja ou capela era algo muito significativo, mas, no contexto do narrador, isso foi substituído pelos camarotes do Teatro de São Carlos, em Lisboa, dando a entender que prosperavam muitos dos costumes estrangeiros chegados a Portugal.

O narrador, então, prossegue com as descrições da casa paroquial e do portal da igreja:

A portada da igreja, de arco tricentrico firmado em pilares polystylos de meio relevo, era o mais claro testemunho da idade provecta do presbyterio. A residencia parochial, originalmente no mesmo estylo, estava já civilisada. Uma porta rectangular substituira a antiga. Esquadriadas estavam, tambem, as duas janellas do sobrado [...] e nos seus postigos da esquerda via-se o moderno conforto das vidraças. Não quero dizer com este elogio á morada do padre prior que a igreja tinha resistido [...] aos progressos da civilisação. Pelo contrario. Estava mais alindada 
ainda. Uma irmandade, ou não sei quem, que entendia na fabrica, havia pintado de ochre tudo o que era pedra, de vermelhão tudo o que era azulejo. As camaras municipaes das grandes cidades, os conegos das collegiadas e sés ainda não passaram do ochre, e uma pobre irmandade da aldeia já tinha, ha vinte anos, vencido a méta a que apenas hoje chegam o municipio e a cathedral. (HERCULANO, 19--b, p. 121-122)

Mais uma vez, insistimos, não são ingênuas as explanações realizadas pela voz narrativa: quando afirma que a casa paroquial, que originalmente tinha o mesmo estilo do templo, já está civilizada e aponta as mudanças realizadas nela - porta retangular, esquadrinhas e vidraças nas janelas - e afirma que isso é um elogio, podemos perceber que está a expor exatamente o contrário. Isso está, igualmente, relacionado com o enredo de "O Parocho da Aldeia (1825)”: a narrativa, em muitos aspectos, propõe reflexões sobre a conservação de costumes pátrios e também sobre o que denomina como progresso advindo das nações economicamente dominantes. Um dos casos mais marcantes, dentre tantos outros na narrativa, é o do escândalo das luxuosas roupas das personagens Manuel e Bernardina, às modas das grandes cidades, frente às indumentárias tradicionais dos saloios no dia da festa de S. Pantaleão, o orago da aldeia (HERCULANO, 19--b, p. 254-255). Contudo, no trecho supratranscrito, o narrador prossegue afirmando que o templo estava ainda mais belo, pois alguma irmandade ou alguém havia coberto as pedras com uma cor uma mistura de óxido de ferro e também recoberto os azulejos - outra marca profundamente portuguesa de origem moura - com vermelhão. Obviamente há uma ironia no dito elogio: metaforicamente, o progresso estava recobrindo as tradições mais antigas da pátria. Isso é perceptível porque a voz narrativa chega mencionar as possíveis campanhas de cônegos e políticos, posteriores à circunscrição da história, de mandarem pintar os patrimônios, apagando a originalidade e, imprimindo neles, as marcas do chamado progresso.

Aliás, Herculano também mostrou a sua preocupação com os patrimônios arquitetônicos de Portugal em textos que acompanham as suas obras literárias. É o caso do prólogo a Eurico, o presbítero, quando menciona os “[...] mosteiros, quando êles desabavam no meio das nossas transformações políticas” (HERCULANO, 19--a: vi) em nítida referência ao que acontecia com os mosteiros e conventos após o decreto de extinção das Ordens Regulares (1834) ${ }^{8}$. Já no prefácio ao romance histórico $O$ Monge de Cistér ou a época de D. João $I^{9}$, o escritor tece considerações acerca de uma das suas pretensões na elaboração da narrativa, igualmente fazendo menções às situações dos patrimônios arquitetônicos de Portugal:

[...] ouve-se um ruído subito, semelhante ao bater no chão de homem de guerra que morre. É o edificio que solta o seu ultimo arranco e vai ajunctar mais uma ossada a milhares dellas que jazem sob os pés da povoação recente. [...] / De

\footnotetext{
${ }^{8}$ Após a vitória dos Liberais, em 1834, numa medida inspirada na Revolução Francesa, houve a promulgação do decreto de extinção das Ordens Regulares em Portugal. De acordo com Rute Andreia Massano Rodrigues (2017, p. 25-26), “[...] em 1834, com a extinção das Ordens Religiosas, os conventos conheceram aquele que foi um verdadeiro processo de 'desmantelamento' que se arrastou, em alguns casos, até as primeiras décadas do século XX [...]. As medidas protagonizadas por D. Pedro IV (17981834), enquanto regente, e pelos diversos governos sob os reinados de D. Maria II (1819-1853) e seus sucessores, D. Pedro V e D. Luís, revelar-se-iam fundamentais, não evitando, contudo, que parte dos recheios conventuais acabassem dispersos e, em algumas situações, mesmo destruídos”.

${ }^{9}$ O Monge de Cistér ou a época de D. João I teve capítulos divulgados, em 1841, no semanal O Panorama. Foi publicado em tomos em 1848. (MENDES, 2017, p. 11).
} 
todas as cidades herdeiras do nome das suas antepassadas é a nossa Lisboa uma daquellas cujo tronco é mais antigo e cujas renovações têem sido mais frequentes. [...] / Com a rapidez da cholera ou da peste corre por todos os angulos de Portugal e encasa-se em todos os povoados uma cousa hedionda e torpe que, inimiga do passado e do futuro, se chama illustração; [...] se chama philosophia. [...] Seu mister é apagar todos os sanctos affectos da alma [...]. Que se apresse aquelle que quizer guardar alguns fragmentos do passado [...]; porque a illustração do vapor e do atheismo social ahi vai livelando [...] as memorias da historia gigante do velho Portugal pelo areal plano e pallido da nossa historia presente [...] / Se eu fosse rico, iria comprar a capellinha, iria comprar o pardieiro onde houvesse a hombreira gothica: os homens do progresso vender-me-hiam isso tudo, porque havia de enganá-los; porque havia de prometter-lhes que converteria aquella em lupanar, este em casa de cambio. Depois, [...] tomaria a meu cargo essas pobres ruinas, amapará-las-hia como um filho [...]. / Mas eu não sou abastado, que posso fazer? [...] / Foi uma dessas meditações artisticas que gerou o pensamento deste livro, o transmitir aos vindouros alguns fragmentos do passado. [...] / É o que resta a quem é pobre. - Não póde tirar os monumentos das garras dos politicos; mas tem liberdade plena de reconstituir em imaginação e povoar aquelles que já não existem. (HERCULANO, 19--d, p. V-XIV)

O escritor refere, no prefácio ao romance histórico, a rapidez das mudanças que se afiguram em Portugal: o chamado progresso nem sempre respeitava as construções mais antigas, que resguardavam as tradições locais. Herculano afirma que as tais transformações eram fruto das ideias Iluministas que adentravam no país: o racionalismo que destruía os afetos e os sentimentos. Ora, pelo trecho transcrito, podemos, se não levarmos em consideração as outras produções do autor, acreditar piamente que Herculano era um reacionário contrário a qualquer renovação ou progresso social. Todavia, como tudo o que envolve o escritor não é tão simples, esse assunto também não se afigura menos complexo. Na verdade, Herculano foi muito ponderado em relação às transformações sociais em Portugal, desconfiando sempre, mas apontando as boas consequências e denunciando o que julgava pernicioso. No caso da destruição dos patrimônios construídos, o escritor não enxergou a situação como um movimento histórico de naturais transformações, optando por resguardar as histórias pretéritas povoando os prédios que já não existiam e figurando-os em seu romance histórico: era a forma possível ao autor que afirmava não poder salvar financeiramente os patrimônios. O lavor do escritor, portanto, era também o da preservação da história pátria, retratando os espaços apagados pelas transformações sociais.

Também em “O Castello de Faria (1373)”, coligida em Lendas e Narrativas, encontramos menções a uma fortificação medieval do Minho, que dá nome ao conto. O narrador, contudo, afirma que "[...] não ha hoje ahi uma unica pedra [...]. As relações dos historiadores foram mais duradouras que o marmore.” (HERCULANO, 19--b, p. 226). A voz narrativa é também uma delas, nessa referida relação de historiadores, que deu notícias do castelo minhoto já materialmente inexistente. O ofício das narrativas históricas seria o de também fazer rememorar o que já não era visível para os leitores, pois às vicissitudes históricas nem sempre resistem as pedras das construções. E, de fato, o narrador povoou o Castelo de Faria e o pormenorizou na narrativa: "O castello de Faria, com suas torres e ameias, com a sua barbacan e fosso, com seus postigos e alçapões ferrados, campeou ahi como dominador dos valles vizinhos. Castello real da idade-média, a sua origem some-se nas trevas dos tempos” (HERCULANO, 19--b, p. 
218). Conforme já verificamos, as descrições dos ambientes se fazem de grande valia para a circunscrição espaciotemporal tão cara ao romance histórico. No caso de narrativas ambientadas na Idade Média, a figuração dos castelos, enquanto ambientes onde se desenrolam a trama, é de suma importância, já que remonta a uma construção de suma importância para o período, conforme explica Jacques Le Goff:

O palácio apresenta duas características específicas que o diferenciam de uma residência real, ou pelo menos principesca, ao passo que o castelo medieval pertence a um simples senhor, embora os reis possam ter construídos castelos medievais enquanto senhores. Além disso, das duas funções essenciais do castelo, a militar e a residencial, é esta última que o palácio privilegia, ao passo que o castelo medieval caracteriza-se pela primeira. (LE GOFF, 2009, p. 90)

O privilegiar da atividade militar na edificação de um castelo medieval, como fortaleza, conforme propõe Le Goff, é ressaltado na narrativa “O Castello de Faria (1373)”, de Herculano, já que o desenrolar do enredo trata da tentativa de defesa dos muros da fortaleza contra as investidas dos castelhanos em Portugal. A mesma função militar da construção é ressaltada em $O$ Bobo (1128). O narrador situa o leitor das funções das muralhas e circunscreve a ambientação da narrativa descrevendo a fortaleza de Guimarães:

O castello de Guimarães, qual existia nos principios do seculo XII, differençava-se entre os outros, que cubriam quasi todas as eminencias das honras e préstamos de Portugal e Galliza, por sua fortaleza, vastidão e elegancia. A maior parte dos edificios desta espécie eram apenas então um aggregado de grossas vigas, travadas entre si, e formando uma serie de torres irregulares, cujas paredes [...] mal resistiam aos golpes dos arietes e aos tiros das catapultas, ao passo que os madeiros que ligavam esses fracos muros [...] tinham o grave inconveniente de poderem facilmente incendiar-se. Assim não havia castello onde entre armas e bastimentos de guerra não occupassem um dos mais importantes logares as amplas cubas de vinagre, liquido que a experiencia tinha mostrado ser o mais proprio para apagar o alcatrão incendido, que como instrumento de ruina usavam nos sitios dos logares afortalezados. [...] / Mas o castello de Guimarães podia, do teso sobre que estava assentado, olhar com tranquillo desdem para os formidaveis e variados engenhos militares de christãos e sarracenos. (HERCULANO, 19--c, p. 15-17)

Ora, se o castelo medieval “[...] está intimamente associado à atividade militar” (LE GOFF, 2009, p. 90), a fortaleza de Guimarães é privilegiada, na descrição do narrador, pois é muito mais fortificada e preparada para os possíveis ataques: o narrador explica, por exemplo, a função primeira do castelo na Idade Média. Vejamos também que a voz narrativa ainda dá notícias ao leitor distante da época em que o romance está ambientado (século XII) de como poderiam ser resolvidos os incêndios de ataques inimigos: é uma nítida preocupação para que se possa visualizar com maior exatidão uma época tão distinta e distante, mas onde repousa os germens da independência do Estado Português e da formação pátria.

É interessante como também em “O Bispo Negro (1130)”, que compõe Lendas e Narrativas, e é um conto ambientado em época próxima ao do romance $O$ Bobo (1128), a formação pátria é exposta na pormenorização da fachada da Sé Velha de Coimbra: 
Houve tempo em que a velha cathedral conimbricense, hoje abandonada de seus bispos, era formosa; houve tempo em que essas pedras, ora tisnadas pelos annos, eram ainda pallidas, como as margens areentas do Mondego. [...] / Então aquellas ameias e torres não haviam sido tocadas de mãos de homens, desde que os seus edificadores as tinham collocado sobre as alturas; e, todavia, já então ninguem sabía se esses edificadores eram da nobre raça goda, se da dos nobres conquistadores arabes. / Mas, quer filha dos valentes do norte, quer dos pugnacissimos sarracenos, ella era formosa, na sua singela grandeza, entre as outras sés das Hespanhas. Ahi succedeu o que ora ouvireis contar. (HERCULANO, 19--b, p. 57-58)

Novamente, temos a figuração, no conto de Herculano, de uma construção importantíssima para a Idade Média, pois, de acordo com Le Goff (2009, p. 50) "Catedral vem do latim cathedra, ou seja, cátedra, uma espécie de trono reservado ao bispo - esse trono episcopal é, aliás, um dos elementos essenciais do interior da catedral. Portanto, a catedral é essencialmente a igreja do bispo”. Em Portugal, o termo Sé remonta a esse mesmo trono como sede episcopal. A representação da Sé Velha Conimbricense - frisamos o termo velha, porque também existe outra construção a Nova Sé, datada do século XVII e sede do governo episcopal de Coimbra desde o século XVIII - foi retratada na narrativa de Herculano não apenas como uma construção, mas o narrador a refere como originária de tempos imemoriáveis e que se perdia, inclusive, a sua possível origem: não se sabia se era uma edificação visigótica ou mourisca, além de que figuram na fachada da igreja ameias e torres, como as fortalezas militares - os castelos - e ambos os povos referidos são descritos como guerreiros e nobres, estando nas raízes do povo de Portugal. Entretanto, há uma nota para explicar a possível ausência de referência histórica em “O Bispo Negro (1130)”: “A sé velha de Coimbra é, no todo ou na maxima parte, uma edificação dos fins do seculo duodecimo; mas acceitamos aqui a tradição que lhe attribue uma remotissima antiguidade.” (HERCULANO, 19--b, p. 57). Historicamente, a edificação da velha catedral data do século XII, mas Paulo Motta Oliveira assim justifica o recurso construído pelo autor nesta narrativa:

[...] é caracterizada pela existência de duas vozes: de um lado a do narrador de tradições, de outro a do historiador, que analisa os materiais justamente para poder separar o que é história daquilo que é lenda. Enquanto a primeira das vozes é a responsável pela narrativa do conto propriamente dita, a segunda aparece principalmente nas notas. Essa presença de uma dupla voz percorre todo o texto. (OLIVEIRA, 2000, p. 135, grifo do autor)

Ou seja, o rememorar legendário da edificação também não é algo ingênuo: a voz narrativa mais uma vez faz menções aos povos que formaram inicialmente o povo português e isso poderia estar, inclusive, figurado na fachada que, embora fosse posterior aos godos e mouros, poderia carregar também as heranças arquitetônicas legadas por esses povos à Península Ibérica. Aliás, a descrição da fachada da igreja que servirá de local para o desenrolar da trama de “O Bispo Negro (1130)”, é também importante porque deixa claro que a construção já foi muito importante, mesmo que esteja abandonada, hoje, de seus bispos e foi “[...] a igreja mais importante [e] [...] a cabeça de todas as igrejas” (LE GOFF, 2009, p. 51). 
Juntamente com as catedrais, Herculano também representou os mosteiros em suas obras literárias. Em Eurico, o presbítero, no capítulo XII, intitulado “O Mosteiro”, há a seguinte descrição do prédio:

O mosteiro da Virgem Dolorosa estava situado numa encosta [...]. Edifício sumptuoso, construído no tempo de Recaredo, as suas grossas muralhas de mármore pareciam, na verdade, quadrelas de castelo roqueiro; [...] Os muros fortíssimos daquele vasto edifício, as suas portas tecidas de ferro e carvalho, as estreitas frestas, que apenas lhe deixavam penetrar no interior uma luz duvidosa, os tetos ameados e, finalmente, os fossos profundos que o circundavam, tudo acomodado para larga defensão. [...] / No centro do imenso edifício erguia-se o templo monástico: peça quadrangular, construída de grossos cantos de mármore [...]. No exterior do templo, no meio de um vasto pátio que o rodeava, viam-se negrejar na sua cinta de estreitas celas [...]. Os seus claustros pacíficos e saüdosos [...] [eram] como um oásis frondoso (HERCULANO, 19--a, p. 120-124)

Ainda que seja uma edificação de origem imaginária, descrita no romance histórico, o mosteiro é referenciado como original do período de Recaredo (559-601), rei dos visigodos. A construção é, igualmente, referida como uma fortaleza parecida com um castelo medieval, "[...] entre as ameias que lhe cingiam a fronte, como coroa de um rei gigante (HERCULANO, 19--a, p. 122)" e isso é interessante, porque, no enredo do romance histórico, ali estavam aquartelados alguns dos guerreiros godos, após a entrada dos árabes na Península Ibérica e também estava refugiada a população em fuga, dando a entender também as múltiplas funções dessas construções e reforçando a ambientação medieval do romance. Interessante é também citar que, na pormenorização do mosteiro visigótico, o templo ocupa lugar central da construção: é o valor de destaque que se dá a oração solenizada dentro da vida monástica tanto feminina quanto masculina, isto é: a própria disposição arquitetônico-religiosa reforça essa presença imaterial "[...] como as festividades, os cantares, as procissões e romarias, as orações, os hinos, a música” (EUSÉBIO, 2017, p. 489).

A descrição, em Eurico, o presbítero, refere também o claustro do mosteiro medieval, que, de acordo com Le Goff (2009, p. 138) é “[...] constituído por um jardim interior rodeado de galerias que se abrem em arcadas para esse jardim. [...] é a ideia de encerramento, enclausuramento, presente na etimologia latina da palavra claustro, claustrum, que vem de claudere, fechar”. Ou seja, a vida monástica, tão presente no ambiente medieval, não deixou de ser retratada nas descrições do romance histórico de Herculano e, em outro texto coligido em Lendas e Narrativas, cujo título faz menção a uma peça arquitetônica, “A Abobada (1401)”, o mosteiro é designado como um "[...] immenso livro de pedra a que os espiritos vulgares chamam simplesmente o mosteiro da Batalha” (HERCULANO, 19--b, p. 234).

E pudera que o narrador de “A Abobada (1401)” denomine o Mosteiro de Santa Maria da Vitória - ou Mosteiro da Batalha - como um livro de pedra: a construção marcou uma época muito complexa de Portugal, pois com a morte do rei D. Fernando I (1345-1383) e a ausência de um descendente masculino, o trono português poderia ser ocupado pelo rei de Castela, Juan I (1358-1390), casado legitimamente com a filha do finado monarca. No entanto, foi coroado, em Portugal, João, o Mestre de Avis (1357-1433), um irmão bastardo de D. Fernando e, no dia 14 de agosto de 1385, travou-se a Batalha de Aljubarrota entre os portugueses e os castelhanos. 
Com a vitória lusitana e a humilhação de Juan I, inaugurou-se uma nova dinastia em Portugal: a de Avis. Para celebrar a vitória e se afirmar no reino, D. João I mandou erigir o Mosteiro de Santa Maria da Vitória - invocação também muito significativa para o feito.

Na narrativa de Herculano, na voz da personagem que projetou o mosteiro, mestre Affonso, temos a seguinte afirmação:

[...] para entender o pensamento do mosteiro de Sancta Maria da Victoria, cumpre ter vivido com a revolução que pôs no throno o mestre d'Aviz; [...] ter vencido em Aljubarrota. Não é este edificio obra de reis, aindaque por um rei me fosse encommendado seu desenho e edificação, mas nacional, mas popular, mas da gente portuguesa, que disse: não seremos servos do estrangeiro e que provou o seu dicto. (HERCULANO, 19--b, p. 243, grifo do autor)

Pela fala de mestre Affonso, percebemos que a narrativa de Herculano tem a preocupação em demonstrar que o tal mosteiro não era apenas um prédio, dentre tantos outros. Por ele, celebrou-se uma segunda independência de Portugal; o mosteiro da Batalha, ainda que encomenda do Mestre de Avis, pertencia ao povo português, que não aceitou o jugo estrangeiro. Ora, perante o contexto complexo do período oitocentista da publicação de Lendas e Narrativas, o rememorar da edificação de Santa Maria da Vitória não é, mais uma vez afirmamos, algo ingênuo ou solto na narrativa: pelo contrário, busca as raízes pátrias no passado, passado que também pode ser lido nos monumentos e livros de pedra e, conforme já abordamos, pode fazer pensar o presente incerto e o futuro nebuloso de Portugal.

Por fim, se recorrermos a respeitável História da Literatura Portuguesa, de António José Saraiva e Óscar Lopes, obra densa e que em muito contribui para os estudos da Literatura Portuguesa, encontraremos a seguinte afirmação acerca da produção literária de Herculano:

[...] sucedem-se as cenas dramáticas de interior, dominadas pelo diálogo e pela descrição minuciosa do ambiente (arquitectura, mobiliário, etc.), as cenas de ar livre (procissões, tumultos e comícios populares, etc.); as reflexões morais-religiosas, a explicação histórico-social. Normalmente cada um destes géneros literários - dramático, narrativo-descritivo, expositivo e didáctico - ocupa o seu capítulo próprio. Não há uma integração perfeita entre estes elementos ligados por contiguidade: a ficção portuguesa em prosa encontra-se ainda em fase incipiente, com Herculano [...]. (SARAIVA; LOPES, 1985, p. 773)

Como tentamos demonstrar, neste estudo, ao contrário do que afirmam Saraiva e Lopes, as narrativas de Herculano não são incipientes e, tampouco, os múltiplos recursos utilizados na elaboração do autor estão desintegrados: obviamente, cada um dos subterfúgios citados pelos críticos merece uma análise mais atenta. Contudo, o que verificamos em nossa colaboração acerca da ambientação e das pormenorizações arquitetônicas é que elas estão bastante integradas às obras em que figuram e também ao contexto de publicação desses textos literários. 


\section{Conclusão}

As recorrentes pormenorizações dos espaços e ambientes, que ocupam, muitas vezes, extensas páginas do texto literário de Herculano, não são ingênuas. Elas, primeiramente, contribuem para situar o leitor do romance histórico no tempo e espaço em que a narrativa está circunscrita e não estão desconectadas dos outros recursos narrativos: na verdade, reforçam, em suas particularidades que analisamos, o que se pode discutir nas obras.

Um dos exemplos disso é de como a pormenorização arquitetônica leva à circunscrição de um ambiente particularmente português, não apenas quando descreve as notórias construções, como a Velha Sé de Coimbra ou o Mosteiro da Batalha, mas também quando remonta espaços imaginários, como a igreja manuelina - que, embora seja um espaço puramente ficcional em “O Parocho da Aldeia (1825)”, não deixa de existir no cenário nacional em muitos exemplares espalhados pelo país. Portanto, a pormenorização arquitetônica em Herculano é uma forma de contar a história pretérita da pátria e pensar os ideais de nacionalidade, temáticas recorrentes no período oitocentista. Ademais, foi também por meio dessas exaustivas ambientações que o autor denunciou o desmantelamento, em nome do progresso, dos patrimônios arquitetônicos, numa concepção que nos figura muito mais como resistência do que como reacionarismo.

\section{Referências}

ALMEIDA, F. de. História da Igreja em Portugal. Tomo I. Porto: Portucalense Editora, 1967.

BAKHTIN, M. Estética da Criação Verbal. São Paulo: Martins Fontes, 1997.

CRUZ, T. A viagem “no largo tempo do Manuelino”. Workshop de Estudos Medievais da Universidade do Porto - 2016, Porto, Incipit 5, p. 78-90, 2017. Disponível em: <https://ler. letras.up.pt/uploads/ficheiros/15111.pdf>. Acesso em: 15 ago. 2019.

EUSÉBIO, M. de F. O legado dos bens culturais. In: FRANCO, J. E.; PEREIRA, J. C. S. (dir.). Portugal Católico: a beleza na diversidade. Lisboa: Círculo de Leitores, 2017. p. 483-487.

HERCULANO, A. Eurico, o presbítero. Lisboa: Bertrand, 19--a.

Lendas e Narrativas. Lisboa: Bertrand, 19--b.

O Bobo (1128). Lisboa: Bertrand, 19--c.

. O Monge de Cistér ou a época de D. João I. Tomos I e II. Lisboa: Bertrand, 19--d.

Scenas de um anno da minha vida e apontamentos de viagem. Lisboa: Bertrand, 19--e.

LE GOFF, J. Heróis e maravilhas da Idade Média. Petrópolis: Vozes, 2009.

LOURENÇO, Eduardo. O Labirinto da Saudade: Psicanálise Mítica do Destino Português. Lisboa: Publicações Dom Quixote, 1992.

LUKÁCS, G. O romance histórico. Tradução de Rubens Enderle. São Paulo: Boitempo Editorial, 2011. 
MARINHO, M. de F. O Romance Histórico em Portugal. Porto: Campo das Letras, 1999. MATTOSO, J. A formação da nacionalidade. In: TENGARRINHA, J. (org.). História de Portugal. São Paulo: UNESP, 2001. p. 31-41.

MENDES, E. S. Alexandre Herculano, entre o Presbítero e o Monge: o (anti)clericalismo e as personagens religiosas em Monasticon (Eurico, o presbítero e O Monge de Cistér). 2017. 254 f. Dissertação (Mestrado em Letras) - Programa de Pós-Graduação em Letras Universidade Federal do Paraná, Curitiba, 2017.

OLIVEIRA, P. M. Alexandre Herculano: malhas da história, armadilhas da ficção. In: BOËCHAT, M. C. B.; OLIVEIRA, P. M.; OLIVEIRA, S. M. P. de (Orgs.). Romance Histórico: recorrências e transformações. Belo Horizonte: FALE/UFMG, 2000. p. 129-149.

PINHO, J. B. de. A herança arquitetônica católica: monumentos e património edificado. In: FRANCO, J. E.; PEREIRA, J. C. S. (Dir.). Portugal Católico: a beleza na diversidade. Lisboa: Círculo de Leitores, 2017. p. 483-487.

RODRIGUES, R. A. M. Entre a salvaguarda e a destruição: a extinção das Ordens Religiosas em Portugal e as suas consequências para o património artístico dos conventos (183401868). 2017. 815 f. Tese (Doutoramento em História) - Faculdade de Letras - Universidade de Lisboa, Lisboa, 2017.

SARAIVA, A. J.; LOPES, O. História da Literatura Portuguesa. Porto: Porto Editora, 1985.

WATT, I. A ascensão do romance: estudos sobre Defoe, Richardson e Fielding. Tradução de Hildegard Feist. São Paulo: Companhia das Letras, 2010.

Recebido em setembro/2019.

Aceito em outubro/2019. 